\title{
Frasier syndrome: four new cases with unusual presentations
}

\section{Síndrome de Frasier: quatro novos casos com apresentação atípica}

Mara Sanches Guaragna', Anna Cristina Gervásio de Britto Lutaif', Viviane Barros Bittencourt ${ }^{3}$, Cristiane Santos Cruz Piveta ${ }^{1,4}$, Fernanda Caroline Soardi', Luiz Claudio Gonçalves Castro5, Vera Maria Santoro Belangero², Andréa Trevas Maciel-Guerra', Gil Guerra-Junior ${ }^{4,7}$, Maricilda Palandi De Mello' $^{1}$

\section{SUMMARY}

Frasier syndrome (FS) is characterized by gonadal dysgenesis and nephropathy. It is caused by specific mutations in the Wilms' tumor suppressor gene (WT1) located in 11p23. Patients with the $46, X Y$ karyotype present normal female genitalia with streak gonads, and have higher risk of gonadal tumor, mainly, gonadoblastoma. Therefore, elective bilateral gonadectomy is indicated. Nephropathy in FS consists in nephrotic syndrome (NS) with proteinuria that begins early in childhood and progressively increases with age, mainly due to nonspecific focal and segmental glomerular sclerosis (FSGS). Patients are generally unresponsive to steroid and immunosuppressive therapies, and will develop end-stage renal failure (ESRF) during the second or third decade of life. We report here four cases of FS diagnosis after identification of WT1 mutations. Case 1 was part of a large cohort of patients diagnosed with steroid-resistant nephrotic syndrome, in whom the screening for mutations within WT1 8-9 hotspot fragment identified the IVS9+5G>A mutation. Beside FS, this patient showed unusual characteristics, such as urinary malformation (horseshoe kidney), and bilateral dysgerminoma. Cases 2 and 3, also bearing the IVS9+5G>A mutation, and case 4, with IVS9+1G>A mutation, were studied due to FSGS and/or delayed puberty; additionally, patients 2 and 4 developed bilateral gonadal tumors. Since the great majority of FS patients have normal female external genitalia, sex reversal is not suspected before they present delayed puberty and/or primary amenorrhea. Therefore, molecular screening of WT1 gene is very important to confirm the FS diagnosis. Arq Bras Endocrinol Metab. 2012;56(8):525-32

\section{SUMÁRIO}

A síndrome de Frasier (SF), caracterizada por disgenesia gonadal e nefropatia, é causada por mutações específicas no gene supressor do tumor de Wilms (WT1) localizado em 11p23. Pacientes com cariótipo 46,XY apresentam genitália feminina normal com gônadas disgenéticas e alto risco de tumor gonadal, principalmente o gonadoblastoma. Por isso, a gonadectomia bilateral eletiva está indicada. A nefropatia na SF consiste de síndrome nefrótica com proteinúria que se inicia na infância e aumenta progressivamente com a idade, principalmente devido à glomeruloesclerose focal e segmentar (GESF). Esses pacientes não respondem ao tratamento com esteroides e imunossupressores e desenvolverão insuficiência renal crônica durante a segunda ou terceira década de vida. Neste trabalho, são relatados quatro casos de SF cujo diagnóstico foi definido após o rastreamento molecular do gene WT1. 0 caso 1 faz parte de um grande grupo de pacientes que tiveram diagnóstico de síndrome nefrótica corticorresistente e no qual o rastreamento de mutações no fragmento 8-9 do gene WT1 identificou a mutação IVS9+5G>A. Além da SF, essa paciente apresentou características incomuns, tais como malformação urinária (rins em ferradura) e disgerminoma bilateral. Os casos 2 e 3 também apresentaram a mutação IVS9+5G>A, e, no caso 4, foi identificada a mutação IVS9+1G>A, sendo que esses três casos foram encaminhados para estudo molecular em decorrência de GESF e/ou atraso no desenvolvimento puberal. Além disso, as pacientes 2 e 4 desenvolveram tumor gonadal bilateral. Visto que a maioria dos pacientes com SF apresenta genitália externa feminina, não há suspeita de sexo reverso até apresentarem atraso puberal e/ou amenorreia primária. Portanto, o rastreamento molecular do gene WT1 é de fundamental importância para se confirmar o diagnóstico de SF. Arq Bras Endocrinol Metab. 2012;56(8):525-32
'Centro de Biologia Molecular e Engenharia Genética, Universidade Estadual de Campinas (Unicamp), Campinas, SP, Brazil

${ }^{2}$ Nefrologia Pediátrica,

Departamento de Pediatria,

Faculdade de Ciências

Médicas (FCM), Unicamp,

Campinas, SP, Brazil

${ }^{3}$ Nefrologia Pediátrica, Irmandade

da Santa Casa de Misericórdia,

Porto Alegre, RS, Brazil

${ }^{4}$ Centro de Investigação em

Pediatria (Ciped), FCM-Unicamp,

Campinas, SP, Brazil

${ }^{5}$ Endocrinologia Pediátrica,

Faculdade de Medicina,

Universidade de Brasília

(UnB), Brasilia, DF, Brazil

${ }^{6}$ Departamento de Genética

Médica e Grupo Interdisciplinar

de Estudos da Determinação e

Diferenciação do Sexo (GIEDDS),

FCM-Unicamp, Campinas, SP, Brazil

${ }^{7}$ Endocrinologia Pediátrica,

Departamento de Pediatria e GIEDDS, FCM-Unicamp,

Campinas, SP, Brazil

Correspondence to:

Gil Guerra-Junior

Departamento de Pediatria,

FCM-Unicamp

13083-887 - Campinas, SP, Brazil

gilguer@fcm.unicamp.br

Received on July/18/2012

Accepted on Sept/20/2012 


\section{INTRODUCTION}

$\mathrm{F}$ rasier syndrome (FS, OMIM " 136680 ) is a rare disorder of sex development defined by $46, \mathrm{XY}$ karyotype, gonadal dysgenesis, and progressive glomerulopathy (1). The great majority of cases present normal female internal and external genitalia, streak gonads, and high risk of developing gonadoblastoma. In addition, a case with 46,XX karyotype and normal ovaries has also been described (2). Glomerular symptoms in FS patients consist on childhood proteinuria and nephrotic syndrome (NS), characterized by focal and segmental glomerular sclerosis (FSGS). Patients are frequently unresponsive to treatment with steroids and immunosuppressors, and progress to end-stage renal failure in adolescence or early adulthood $(3,4)$.

FS and Denys-Drash syndrome (DDS, OMIM ${ }^{\#} 194080$ ) are two overlapping diseases, characterized by nephrotic syndrome associated with either diffuse mesangial sclerosis in DDS, or focal segmental glomerular sclerosis in FS, genitourinary defects, and higher risk of developing tumors, such as Wilms' tumor in DDS, and gonadal tumor in both DDS and FS $(5,6)$. Although not frequently observed in FS patients, Wilms' tumor has been reported (7).

Different mutations in the Wilms' tumor suppressor gene $(W T 1$, OMIM *607102) located in 11 p23 may cause either DDS or FS. WTI gene contains ten exons that encode a transcription factor with four zinc finger motifs, essential for both renal and genital normal development. Two main alternative splicings produce four WTl isoforms: two of them differ from each other by the presence or absence of 17 amino acids encoded by exon 5 ; and the other two are distinguished by the inclusion or exclusion of the amino acids lysine, threonine, and serine (KTS) between zinc fingers 3 and 4 as a result of two active splice donor sites in intron 9 (Figure 1). The normal WTl isoform ratio is $2 \mathrm{KTS}(+)$ : $1 \mathrm{KTS}(-)$. This ratio is considered to be temporally and spatially stable during development and throughout life (8). In general, FS patients carry mutations that affect the $2: 1$ ratio for WTI KTS isoforms located in the intron 9 donor splice site, while mutations in patients with DDS are mostly missense $(80 \%)$ within zinc fingers 2 and 3 comprised by exons 8 and 9 (8). Based on those data, exons 8,9 , and intron 9 are considered hotspots for mutations in both conditions. Therefore, the sequence spanning from exon 8 to intron 9 is usually called $W T 1$ 8-9 hotspot fragment.

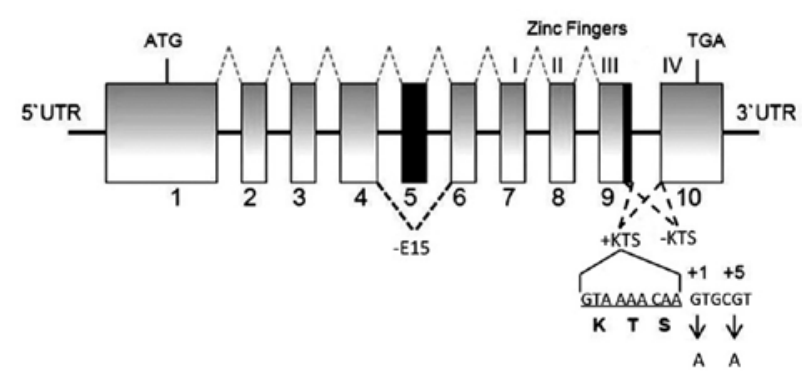

Figure 1. Representation of the WT1 exons and introns showing splicing from 1 to 9 to form WT1 isoform with exon 5 (dashed grey lines above boxes) and three alternative splicing events (dashed black lines below boxes) leading to isoforms without exon 5 (-E5), and either +KTS or -KTS. The nucleotide sequence coding for KTS is denoted. Frasier syndrome results from $\mathrm{G}>\mathrm{A}$ nucleotide change at +1 (case 4 ) and +5 (cases 1, 2, 3) intronic position after KTS coding sequence. Inactivation of intron 9 splice donor site to form +KTS isoform is the result of these mutations. Exon numbers are presented below boxes. ATG and TGA correspond to translation start and stop codons, respectively.

The diagnosis of FS is often suspected upon evaluation of delayed puberty or primary amenorrhea in patients with nephrotic syndrome, focal segmental glomerular sclerosis, or end stage renal failure awaiting kidney transplantation, and it is confirmed by demonstrating mutations in the WTl gene.

Here, we report four new cases of FS in which IVS9+lG>A and IVS9+5G>A WTI mutations were identified. Case 1 was part of a large cohort of patients that had the diagnosis of steroid-resistant nephrotic syndrome (SRNS), in whom the screening for mutations within WT1 8-9 hotspot fragment identified the IVS9+5G>A mutation. Beside FS, this patient showed unusual characteristics, such as urinary malformation and bilateral dysgerminoma. Cases 2 and 3 , also bearing IVS $9+5 \mathrm{G}>\mathrm{A}$ mutation, and case 4 , with IVS $9+\mathrm{lG}>\mathrm{A}$ mutation, were studied due to FSGS and/or delayed puberty; additionally, patients 2 and 4 had developed bilateral gonadal tumor.

\section{MATERIALS AND METHODS}

Genomic DNA extraction from peripheral blood leukocytes was performed by standard techniques (9). The WT1 8-9 hotspot fragment was amplified by PCR with specific primers (exon 8: forward 5'-TAC CCT AAC AAG CTC CAG GG-3'; reverse 5'-GAG AAT CAT GAA ATC AAC CCT AG-3' and exon 9: forward 5'TGA GGC AGA TGC AGA CAT TG-3'; reverse -5'TCT CTC AAC TGA GTC TAA ACC TTA G-3'). The final volume for all reactions was $50 \mu \mathrm{L}$ and contained 10X Taq DNA polymerase buffer (Invitrogen, CA, 
USA), $1.5 \mathrm{mM} \mathrm{MgCl}, 2 \mathrm{mM}$ of each dNTP, 20 pmol of each primer, 300-500 ng genomic DNA templates, and 2 units of recombinant Taq DNA polymerase (Invitrogen). After a first denaturation step $\left(5 \mathrm{~min}, 94^{\circ} \mathrm{C}\right)$, the cycling profile was: $94^{\circ} \mathrm{C}, 1 \mathrm{~min} ; 54^{\circ} \mathrm{C}, 1 \mathrm{~min}$; $72^{\circ} \mathrm{C}, 2 \mathrm{~min}(30$ cycles $)$, followed by $5 \mathrm{~min}$ at $72^{\circ} \mathrm{C}$ (final extension). The size of the PCR products was determined in $1 \%$ agarose gel electrophoresis stained with ethidium bromide. Before sequencing, purification of PCR products was performed using the Wizard ${ }^{\circledR}$ SV Gel and PCR clean-up system (Promega, Madison, WI, USA). Further direct sequencing using ABI PRISM Big Dye Terminator v3.1 Cycle Sequencing Kit (ABI PRISM/PE Biosystems, Foster City, CA, USA) was carried out in four reactions, using sense and antisense primers. The sequences were obtained in an automatic sequencer ABI PRISM 3130 DNA Analyzer (ABI PRISM/PE Biosystems). The free softwares Chromas Pro v.1.5 and CLC Sequence Viewer v.6.6.2 were used to analyze and compare sequences with the published WTI (ENSG00000184937) sequence at Ensembl database (www.ensembl.org). Y-chromosome sequence analysis was conducted by PCR and nested-PCR with primers for SRY gene, TSPY gene and Y-centromeric region DYZ3, as described elsewhere (10). After PCR amplification, reaction products $(10 \mu \mathrm{l})$ were submitted to $2 \%$ agarose gel electrophoresis stained with ethidium bromide and using a molecular weight marker. Each PCR reaction contained normal female and male controls (data not shown). Chromosome analyses were performed on peripheral blood lymphocytes using standard techniques and 50-G banded metaphases were evaluated.

\section{CASE REPORTS}

\section{Case 1}

A 7-year-old female child was included in a study in which the screening for mutations within WTI 8-9 hotspot fragment was being performed in a group of patients with steroid-resistant nephrotic syndrome (SRNS). She had been followed up in the Pediatric Nephrology Outpatient Clinic from Clinical Hospital of State University of Campinas (Unicamp) - Brazil, since she was 5.1 years old, due to persistent edema and proteinuria. She was initially treated with prednisone $2 \mathrm{mg} / \mathrm{kg} /$ day for 8 weeks. After that, she received cyclophosphamide and prednisone during another pe- riod of 8 weeks, when an increment in albuminemia and a decrease in proteinuria were observed. However, the condition relapsed one week after the withdrawal of cyclophosphamide. Serum cholesterol level was very high, there was no hematuria, and renal function was normal. Ultrasound showed horseshoe kidney, uretrocystography did not show reflux, and DMSA scintigraphy revealed mild bilateral decrease of tubular function, without scars. As she remained without remission and a kidney biopsy was not indicated, she received cyclosporine A associated with angiotensin receptor blocker, statin, vitamin $\mathrm{D}$, and cephalexin for urinary infection prophylaxis during 18 months. There was a positive clinical response with those therapies, with stabilization of albumin and cholesterol levels and renal function. After this period, there was an increase in $\alpha$-microglobulin levels suggesting tubular lesion. Therefore, cyclosporine A was suspended. The IVS9+5G>A WTI heterozygous mutation was identified (Figure 2). The search for Y-chromosome sequences by PCR was positive, and the $46, \mathrm{XY}$ chromosomal constitution was confirmed by karyotyping (data not shown). Because of the increased risk of gonadoblastoma in such cases, gonadectomy was performed. On histopathology, there was bilateral dysgerminoma (Figures $3 \mathrm{~A}$ and $3 \mathrm{~B}$ ). Thirty months after surgery, neither abdominal and thoracic computed tomography $(\mathrm{CT})$ nor pelvic magnetic resonance imaging (MRI) showed postoperative spreading or reemergence of the tumor. At the age of 10 years, she presented ESRF, which led to peritoneal dialysis during one month before she received kidney transplantation.
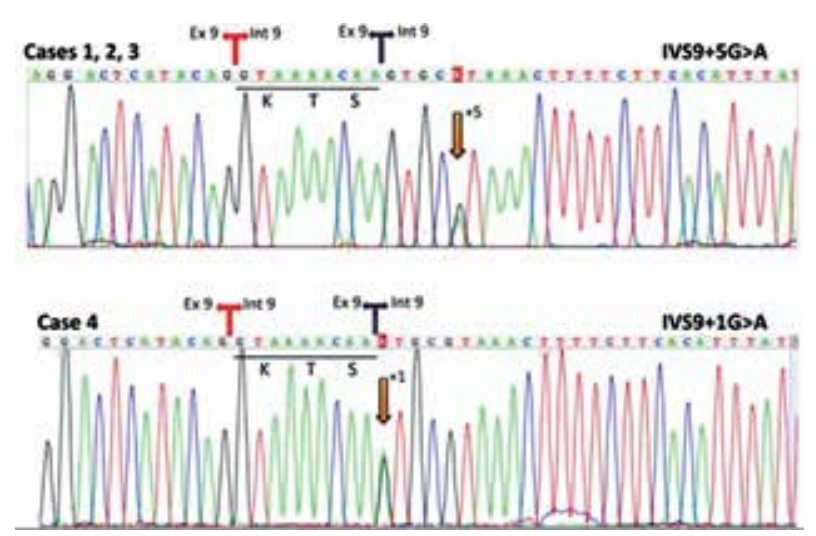

Figure 2. Electropherograms of WT1 exon 9 and intron 9 bordering sequences. The splice sites for -KTS and +KTS isoforms are shown in red and dark blue, respectively. Arrows show the IVS9+5G>A heterozygous mutation in cases $1,2,3$, and the IVS9+1G $>$ A heterozygous mutation in case 4 . The KTS motif is underlined in each sequence. 

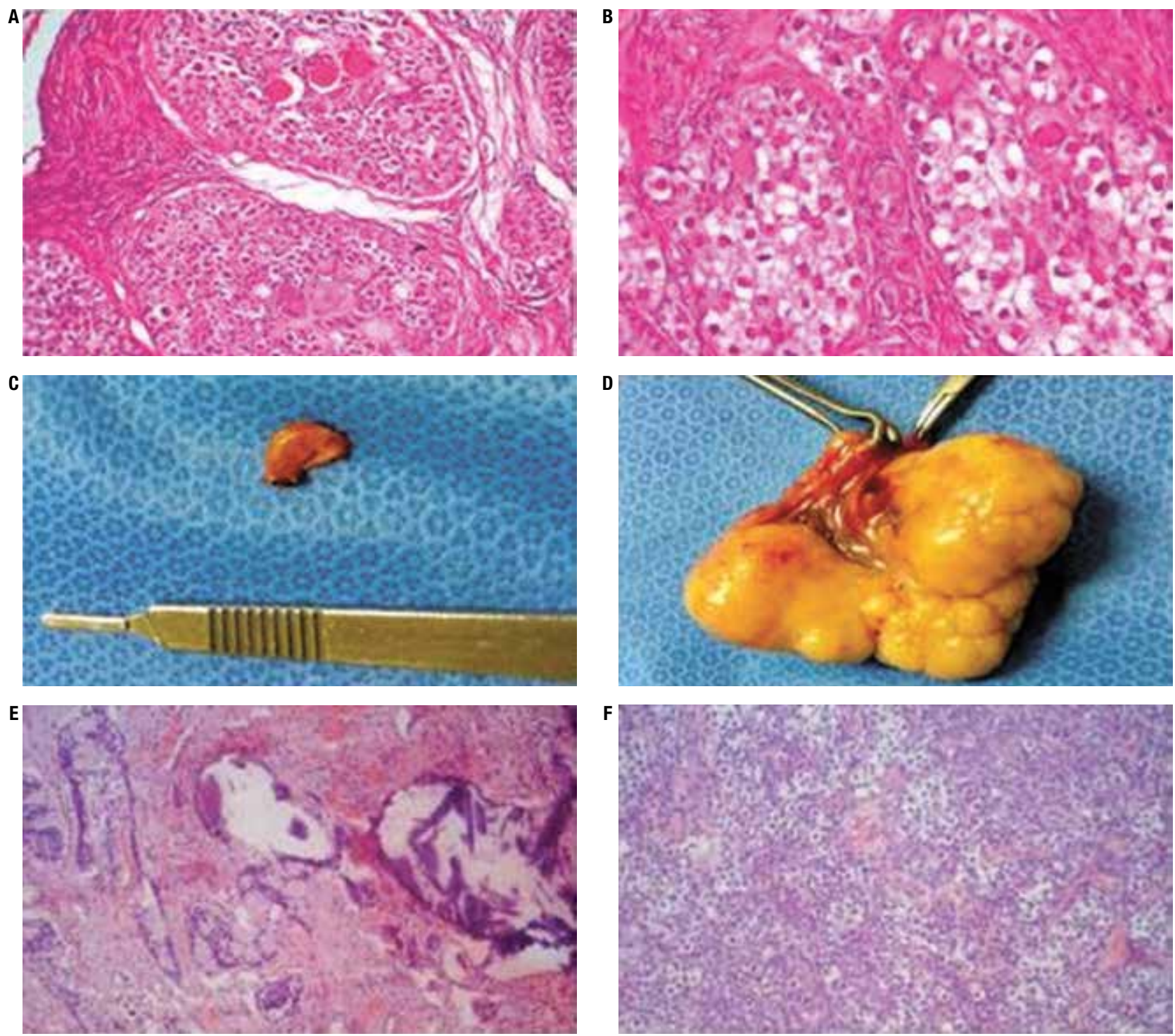

Figure 3. Gonadal morphology of case 1 (A: right dysgerminoma, H\&E, 100x; B: left dysgerminoma, H\&E, 400x); case 2 (C: dysgenetic gonad with gonadoblastoma, macroscopy; D: gonadoblastoma with dysgerminoma, macroscopy); and case 4 (E: gonadoblastoma and dysgerminoma, H\&E, 40x; F: H\&E, 100X).

\section{Case 2}

A female child was seen at the Pediatric Nephrology Outpatient Clinic from Santo Antonio Children's Hospital of Porto Alegre - Brazil. She had been conceived by artificial insemination and was born with 32 weeks of gestation. She was a healthy child, and was in the $75^{\text {th }}$ growth percentile until the age of 8 years and 9 months. Then, she began to lose weight and to show delayed growth. Upon investigation, renal dysfunction was diagnosed and renal biopsy revealed FSGS at the age of 9 years. She did not respond to steroids and cyclosporine. At the age of 10 years and 10 months, she was submitted to bilateral nephrectomy and received a living donor kid- ney transplant. Tacrolimus, sodium micophenolate, and prednisone treatment were started then, and have been maintained up to the present moment. Before starting immunosuppressive therapy, gonadotropin levels were evaluated, and were in the normal range for prepubertal females. When she was 11 years old, she developed spontaneous puberty, reaching breast development Tanner stage 3 and pubic hair Tanner stage 3 at the age of 13 years; however, menarche was absent. At this time, a new hormone evaluation showed low inhibin levels $(<32$ $\mathrm{pg} / \mathrm{mL}$ ), and hypergonadotrophic hypogonadism ( $\mathrm{LH}$ $=76 \mathrm{IU} / \mathrm{L}$ and FSH $=195 \mathrm{IU} / \mathrm{L})$. Pelvic ultrasonography and magnetic resonance showed a small uterus, 
and a long $(\sim 12 \mathrm{~cm})$ and a small $(\sim 1 \mathrm{~cm})$ structure at the left and right gonad topography, respectively; lymph nodes were not visualized. The karyotype was $46, \mathrm{XY}$ and a search for Y-chromosome sequences was positive (data not shown). WTl genotyping indicated heterozygosis for the IVS9+5G>A mutation (Figure 2). Tumoral markers, such as alpha-fetoprotein and human chorionic gonadotropin were elevated, and bilateral gonadectomy was performed at 13 years of age. Histopathology revealed bilateral gonadoblastoma associated with dysgerminona in the left gonad (Figures 3C and 3D). Oncologists and nephrologists decided to maintain her under conservative follow-up, without chemotherapy or changes in the immunosuppressant treatment. After 17 months of surgery, tumoral markers were negative, and abdominal and thoracic computed tomography (CT) and pelvic magnetic resonance imaging (MRI) did not show spreading or reemergence of the tumor. Nowadays, at 15 years of age, she receives estrogen and progesterone therapy, is in Tanner stage B5P5, presents cyclical menses, and her growth remains within the $75^{\text {th }}$ percentile. Renal and hepatic biochemical evaluations are within the normal range.

\section{Case 3}

Patient 3 was also followed up in Pediatric Nephrology Outpatient Clinic from Santo Antonio Children's Hospital of Porto Alegre - Brazil. At the age of 4 years, she developed SRNS. Biopsy showed FSGS, and the patient did not respond to a course of cyclosporine. When she was 9 years old, she developed ESRF, leading to renal transplantation at age of 10 . With the age of 14 years, she had not initiated breast development, indicating delayed puberty associated with primary amenorrhea, slight clitoromegaly, and hypergonadotrophic hypogonadism $(\mathrm{LH}=$ $97 \mathrm{IU} / \mathrm{L}$ and FSH = $192 \mathrm{IU} / \mathrm{L}$ ). Karyotype was 46,XY. A search for Y-chromosome sequences was positive (data not shown). Upon WTI 8-9 hotspot fragment sequencing, she presented the IVS $9+5 \mathrm{G}>\mathrm{A}$ heterozygous mutation (Figure 2). At age of 15 years, bilateral gonadectomy was performed and no tumor was identified (data not shown). Nowadays, she is initiating sex hormone replacement and maintains normal graft function. Immunossupression treatment has not been changed.

\section{Case 4}

This female child was also followed up at Pediatric Nephrology Outpatient Clinic from Santo Antonio Children's Hospital of Porto Alegre - Brazil. She was diagnosed with ESRF at the age of 9 years. She started dialysis immediately after the diagnosis. The etiology of renal failure was attributed to a history of recurrent urinary infections and vesicoureteral reflux. Additionally, a detailed clinical history revealed recurrent edema episodes, which had not been investigated before. At the age of 10, the patient underwent renal transplantation with good initial outcome. After the third year of transplantation, worsening of graft function was observed, with signs of mild chronic allograft nephropathy. Biopsy was not performed. The patient started puberty spontaneously at 11 years old, reaching breast development Tanner stage 4 and pubic hair Tanner stage 4 at 14 years old, without menstruation. At that time, she presented hypergonadotrophic hypogonadism $(\mathrm{LH}=76 \mathrm{IU} / \mathrm{L}$ and $\mathrm{FSH}=92 \mathrm{IU} / \mathrm{L})$ and evident clitoromegaly. Karyotyping was performed resulting in 46,XY, and a search for Y-chromosome sequences was positive (data not shown). The analysis of WT1 8-9 hotspot fragment revealed the IVS9+1G $>$ A heterozygous mutation (Figure 2). Bilateral gonadectomy was performed showing gonadoblastoma associated with bilateral dysgerminoma (Figures $3 \mathrm{E}$ and $3 \mathrm{~F}$ ). Abdominal and thoracic computed tomography (CT) and pelvic magnetic resonance imaging (MRI) indicated no spreading or reemergence of the tumor to date, but the levels of human chorionic gonadotropin did not diminish. Therefore, chemotherapy was started and immunosuppression with tacrolimus+mycophenol ate+prednisone was replaced by sirolimus+prednisone treatment. After 30 months of follow-up, she did not present any signs of metastases. She is receiving hormonal replacement with normal pubertal development and menstruation. Graft function has decreased after chemoterapy and decreased immunossupression. Her creatinine level is $2.4 \mathrm{mg} / \mathrm{dL}$.

\section{DISCUSSION}

In the present study, we analyzed the WTI 8-9 hotspot fragment of four patients with FS. Their follow-up, tumor characteristics and molecular data are summarized in table 1 . Heterozygous mutations in the second alternative splice donor site of intron 9 were found in all cases. The IVS9+5G>A mutation, identified in cases 1 , 2 and 3 , has already been described, and is well correlated with FS $(8,11)$. The IVS $9+1 \mathrm{G}>\mathrm{A}$ mutation, identified in case 4 , was described for the first time in a FS patient by Myioshi and cols. (12). Intron 9 splice 
Table 1. Clinical and laboratory data from four patients with Frasier syndrome

\begin{tabular}{|c|c|c|c|c|c|c|c|c|c|c|c|c|}
\hline \multirow{4}{*}{ Case } & \multirow{4}{*}{ Current } & \multicolumn{7}{|c|}{ Age (years) } & \multirow{2}{*}{\multicolumn{2}{|c|}{ Gonadal tumor }} & \multirow{4}{*}{ Associated conditions } & \multirow{4}{*}{ WT1 mutation } \\
\hline & & \multicolumn{3}{|c|}{ Diagnosis } & \multicolumn{4}{|c|}{ Treatment } & & & & \\
\hline & & \multirow{2}{*}{ NS } & \multirow{2}{*}{ FSGS } & \multirow{2}{*}{ ESRF } & \multirow{2}{*}{ KTx } & \multirow{2}{*}{ GOx } & \multicolumn{2}{|c|}{ Puberty } & \multirow{2}{*}{ Right } & \multirow{2}{*}{ Left } & & \\
\hline & & & & & & & Spontaneous & Induced & & & & \\
\hline 1 & 10.5 & 5.1 & - & 10.0 & 10.1 & 7.3 & - & - & Dys & Dys & Bilateral horseshoe kidneys & IVS9+5G $>A$ \\
\hline 2 & 15.1 & - & 9.0 & 8.8 & 10.8 & 13.0 & 11.0 (B3P3) & 13.0 & Gon & Gon + Dys & - & IVS9+5G>A \\
\hline 3 & 15.3 & 4.0 & 4.3 & 9.0 & 10.0 & 14.0 & - & 14.3 & - & - & Clitoromegaly & IVS9+5G>A \\
\hline 4 & 16.5 & - & - & 9.0 & 10.0 & 14.0 & 11.0 (B4P4) & 14.0 & $\begin{array}{l}\text { Gon/ } \\
\text { Dys }\end{array}$ & Gon/Dys & $\begin{array}{l}\text { Vesicoureteral reflux } \\
\text { Clitoromegaly }\end{array}$ & IVS9+1G>A \\
\hline
\end{tabular}

B: breast development; Dys: dysgerminoma; ESRF: end-stage of renal failure; FSGS: focal and segmental glomerulosclerosis; Gon: gonadoblastoma; GOx: gonadectomy; KTx: kidney transplantation; NS: nephrotic syndrome; P: pubic hair development.

mutations affect the $\mathrm{KTS}(+)$ isoform production and impair the 2:1 ratio for KTS(+) and KTS(-) isoforms, respectively, which are important for the normal development of the glomerular podocytes and for male sex determination (13).

Type II germline cell tumors of the testes and dysgenetic gonads are, by far, the most frequently occurring and feared tumors in 46,XY DSD patients. Carcinoma in situ is virtually the only precursor lesion found in patients with undervirilization syndromes arising in well-differentiated testicular tissue. Nevertheless, nearly all in situ neoplastic lesions in patients with dysgenetic gonads are gonadoblastomas, either overgrown or not by dysgerminoma. If the gonad is considered a testis, invasive type II germline cell tumors found in of 46,XY DSD patients are seminomas, whereas if the gonad is dysgenetic or considered an ovary, the tumor is a dysgerminoma $(14,15)$.

According to Lee and cols. (16) in the Consensus Statement on Management of Intersex Disorders, FS has the highest risk ( $60 \%)$ of develop germline cell tumors, the great majority being gonadoblastomas. In this study, three out of four patients presented bilateral tumors. Case 1 had isolated dysgerminomas in the two gonads; case 2 had an isolated gonadoblastoma in the right gonad, and a dysgerminoma associated with gonadoblastoma in the left gonad; and case 4 had a dysgerminoma associated with gonadoblastoma in both gonads. In the review by Joki-Erkkilä and cols. (17) published in 2002, only three FS patients were reported as presenting dysgerminomas $(3,17,18)$. After that, three cases were reported: a 17-year-old FS patient with a non-informed WTI heterozygous mutation with gonadoblastoma and dysgerminoma in each gonad (19); an 11 -year-old FS patient with IVS9+5G>A WTI het- erozygous mutation, with bilateral dysgerminoma and a pilocytic astrocytoma (20); and a 13-year-old FS patient with IVS9+4C>T WTI heterozygous mutation, with unilateral dysgerminoma, totalizing six FS cases with dysgerminoma to date.

Therefore, patients 1, 2, and 4 presented here are novel cases of young patients with FS and bilateral gonadoblastoma associated with dysgerminoma and submitted to bilateral gonadectomy, with neither resurgence nor metastasis appearing during follow-up. Generally, if the presence of metastasis is observed, chemotherapy should be the first-line of treatment for dysgerminoma, but it is important to have in mind that there is no specific tumor marker, that chemotherapy may worsen renal function, and that kidney transplantation may not be carried out at the same time (21). Because of this, it is advisable that kidney transplantation should not be done until two years after gonadectomy in FS (21). Unfortunately, two patients described here (cases 2 and 4 ) had kidney transplantation before gonadectomy. However, this did not cause any negative consequences. Since patient 2 developed donor specific antibodies, it was decided to decrease immunossupressive treatment. Since there were no signs of metastases and human chorionic gonadotropin level normalized promptly, chemotherapy was also not carried out. It is not possible to determine if immunossupression due to kidney transplantation in cases 2 and 4 has contributed to the appearance of the malignant tumor, or if it would have occurred even in the absence of immunossupression, but these patients were submitted to unnecessary risk of metastases.

To our knowledge, this is the first report of a FS patient with a horseshoe kidney, which is one of the most common congenital anomalies of the genitourinary sys- 
tem (22). It is frequently associated with anomalies of other systems in which genetic factors may play a common etiological role, including musculoskeletal, cardiovascular, and gastrointestinal systems, as well as in certain neurological conditions (23). The occurrence of glomerulonephritis in horseshoe kidney has already been reported (24-27), with focal and segmental glomerulosclerosis described in two cases $(25,27)$.

Since the great majority of FS patients have normal female external genitalia, sex reversal is not suspected until later in life, when these patients report delayed puberty and/or primary amenorrhea. In general, delayed puberty in patients with chronic disease, like renal disease, is due to hypogonadotrophic hypogonadism, but in FS patients it is due to hypergonadotrophic hypogonadism, since they present dysgenetic gonads. Therefore, evaluation of LH, and mainly FSH, is mandatory in all patients with chronic renal disease without normal puberty, and if those levels are elevated, karyotyping should be performed (28), since XY patients have been reported to have high risk of gonadal tumors (14-16). It is interesting to observe that, although cases 2 and 4 have begun puberty spontaneously, they did not reach complete puberty with menstruation, and that cases 3 and 4 presented clitoromegaly. Joki-Erkkilä and cols. (17) showed that almost $75 \%$ of the FS patients with gonadal tumors (gonadoblastoma and/or dysgerminoma) developed spontaneous puberty. These authors found positivity for inhibin, estrogen, and progesterone receptors in gonadal stroma and gonadal tumors of FS patients, and they speculated that dysgenetic gonads with or without tumors could be targets for hormonal activity.

This far, it is also important to note that if patients with SRNS and WTI mutations remain unrecognized, they may be treated with potentially systemic toxic drugs, without any evidence of benefit. Therefore, this paper and other recent reports emphasize the importance of screening patients with SRNS for WTI mutations $(4,29)$.

Finally, this study highlights that FS phenotypes may be variable and sometimes unexpected. Importantly, when FS is suspected, molecular evaluation must be performed, once only the identification of WTI mutations supports definitive diagnosis, which is essential for establishing the most adequate clinical and surgical approaches and management of those patients. In conclusion, if all those issues are considered, unnecessary and ineffective treatments, as well as postponing the right moment for gonadectomy, would be avoided.
Acknowledgements: the authors are grateful for the financial support for provided by a research grant from the National Council for Scientific and Technological Development (CNPq 478444/08-7 to G.G-J and 141072/2010-5 to MSG).

Disclosure: no potential conflict of interest relevant to this article was reported.

\section{REFERENCES}

1. Frasier SD, Bashore RA, Mosier HD. Gonadoblastoma associated with pure gonadal dysgenesis in monozygotic twins. J Pediatr. 1964;64:740-5.

2. Demmer L, PrimackW, LoikV, Brown R, Therville N, McElreavey K. Frasier syndrome: a cause of focal segmental glomerulosclerosis in a 46,XX female. J Am Soc Nephrol. 1999;10:2215-8.

3. Chernin G, Vega-Warner V, Schoeb DS, Heeringa SF, Ovunc B, Saisawat $\mathrm{P}$, et al. Genotype/phenotype correlation in nephrotic syndrome caused by WT1 mutations. Clin J Am Soc Nephrol. 2010;5:1655-62.

4. Bache M, Dheu C, Doray B, Fothergill H, Soskin S, Paris F, et al. Frasier syndrome, a potential cause of end-stage renal failure in childhood. Pediatr Nephrol. 2010;25:549-52.

5. McTaggart SJ, Algar E, Chow CW, Powell HR, Jones CL. Clinical spectrum of Denys-Drash and Frasier syndrome. Pediatr Nephrol. 2001;164:335-9.

6. Melo KF, Martin RM, Costa EM, Carvalho FM, Jorge AA, Arnhold IJ, et al. An unusual phenotype of Frasier syndrome due to IVS9 $+4 \mathrm{C}>\mathrm{T}$ mutation in the WT1 gene: predominantly male ambiguous genitalia and absence of gonadal dysgenesis. J Clin Endocrinol Metab. 2002;87:2500-5.

7. Barbosa AS, Hadjiathanasiou CG, Theodoridis C, Papathanasiou A, Tar A, Merksz M, et al. The same mutation affecting the splicing of WT1 gene is present on Frasier syndrome patients with or without Wilms' tumor. Hum Mutat. 1999;13:146-53.

8. Barbaux S, Niaudet P, Gubler MC, Grunfeld JP, Jaubert F, Kuttenn F, et al. Donor splice-site mutations in WT1 are responsible for Frasier syndrome. Nat Genet. 1997;17:467-70.

9. Sambrook J, Fristsch EF, ManiatisTE. Molecular cloning: a laboratory manual. Cold Spring Harbor, NY: Cold Spring Harbor Laboratory Press; 1989.

10. Alves C, Braid Z, Coeli FB, de Mello MP. 46,XX male - testicular disorder of sexual differentiation (DSD): hormonal, molecular and cytogenetics studies. Arq Bras Endocrinol Metab. 2010;54(8):685-9.

11. Klamt B, Koziell A, Poulat F, Wieacker P, Scambler P, Berta P, et al. Frasier syndrome is caused by defective alternative splicing of WT1 leading to an altered ratio of WT1 +/-KTS splice isoforms. Hum Mol Genet. 1998;7:709-14.

12. Myioshi Y, Santo Y, Tachikawa K, Namba, N, Hirai H, Mushiake S, et al. Lack of puberty despite elevated estradiol in a 46,XY phenotypic female with Frasier syndrome. Endocr J. 2006;53(3):371-6.

13. Bruening W, Bardeesy N, Silverman BL, Cohn RA, Machin GA, Aronson AJ, et al. Germline intronic and exonic mutations in the Wilms tumor gene (WT1) affecting urogenital development. Nat Genet. 1992;1:144-8.

14. Looijenga LH, Hersmus $R$, de Leeuw BH, Stoop $H$, Cools $M$, Oosterhuis JW, et al. Gonadal tumours and DSD. Best Pract Res Clin Endocrinol Metab. 2010;24:291-310.

15. Cools M, Drop SL, Wolffenbuttel KP, Oosterhuis JW, Looijenga LH. Germ cell tumors in the intersex gonad: old paths, new directions, moving frontiers. Endocr Rev. 2006;27:468-84.

16. Lee PA, Houk CP, Ahmed SF, Hughes IA; International Consensus Conference on Intersex organized by the Lawson Wilkins Pedi- 
atric Endocrine Society and the European Society for Paediatric Endocrinology. Consensus statement on management of intersex disorders. International Consensus Conference on Intersex. Pediatrics. 2006;118:e488-500.

17. Joki-Erkkilä MM, Karikoski R, Rantala I, Lenko HL, Visakorpi T, Heinonen PK. Gonadoblastoma and dysgerminoma associated with $X Y$ gonadal dysgenesis in an adolescent with chronic renal failure: a case of Frasier syndrome. J Pediatr Adolesc Gynecol. 2002;15:145-9.

18. Haning RV Jr, Chesney RW, Moorthy AV, Gilbert EF. A syndrome of chronic renal failure and $\mathrm{XY}$ gonadal dysgenesis in young phenotypic females without genital ambiguity. Am J Kidney Dis. 1985;6:40-8.

19. Love JD, DeMartini SD, Coppola CP. Prophylactic bilateral salpingooopherectomy in a 17-year-old with Frasier syndrome reveals gonadoblastoma and seminoma: a case report. J Pediatr Surg. 2006;41:e1-4.

20. Subbiah V, Huff V, Wolff JE, Ketonen L, Lang FF Jr, Stewart J, et al. Bilateral gonadoblastoma with dysgerminoma and pilocytic astrocytoma with WT1 GT-IVS9 mutation: a 46 XY phenotypic female with Frasier syndrome. Pediatr Blood Cancer. 2009;53:1349-51.

21. Mestrallet G, Bertholet-Thomas A, Ranchin B, Bouvier R, Frappaz $D$, Cochat $P$. Recurrence of a dysgerminoma in Frasier syndrome. Pediatr Transplant. 2011;15:e53-5.
22. Kolln CP, Boatman DL, Schmidt JD, Flocks RH. Horseshoe kidney: a review of 105 patients. J Urol. 1972;2:203-4.

23. Boatman DL, Kolln CP, Flocks RH. Congenital anomalies associated with horseshoe kidney. J Urol. 1982;107:205-7.

24. Chen A, Ko W-S. Horseshoe kidney and membranous glomerulonephropathy. Nephron. 1990;54:283-4.

25. Abson C, Jones M, Palmer A, Persey M, Gabriel R. Horseshoe kidney, focal and sclerosing glomerulonephritis and primary hypothyroidism. Nephron. 1991;58:124.

26. Fujimoto S, Hirayama N, UchidaT, Lemura F, Yamamato Y, EtoT, et al. Horseshoe kidney and membranous glomerulonephritis with cold activation of complement. Intern Med. 1992;31:625-8.

27. Kayatas M, Ürün Y. Two cases with horseshoe kidney in association with nephrotic syndrome: is there a casual relationship between two conditions? Ren Fail. 2007;29:517-8.

28. Palmert MR, Dunkel L. Clinical practice. Delayed puberty. N Engl J Med. 2012;366:443-53.

29. Santín S, Bullich G, Tazón-Vega B, García-Maset R, Giménez I, Silva I, et al. Clinical utility of genetic testing in children and adults with steroid-resistant nephrotic syndrome. Clin J Am Soc Nephrol. 2011;6(5):1139-48. 